\title{
EDITORIAL
}

\section{Visit to Ghana}

The Editor again has had the privilege of a visit to one of the countries where active and extensive leprosy control has been in progress. We received the invitation of the Hon. The Minister of Health, Ghana, and arrived in Accra on 16th April, 1958, and left again for London on 30th April. Dr. A. McKelvie the specialist leprologist in charge of the Ghana Leprosy Service met us at the airport and personally accompanied us throughout a very strenuous but eminently satisfactory tour of much of the leprosy work in Ghana, and extraordinary kindness and assistance was given by everybody in the Ministry and throughout the tour. It is twelve years since the Medical Secretary of BELRA visited Ghana. At that time it was Dr. Ernest Muir, who had previously visited the country in 1936, and whose wise advice has been the basis for the attack on leprosy which is going so strongly today.

Sparing the reader the details of the missions, hospitals, and clinics visited; it will suffice to say that by hard work and much travel, an extremely full contact was obtained with the leprosy work in progress, and above all it was possible to see a very large number of leprosy patients under treatment and the staff who are actively engaged. The competence and good spirit of the staff were everywhere apparent. Ghana contains a population of over 5,000,000, rather unevenly distributed, and leprosy surveys indicated an incidence of 50,000 cases of leprosy. Dr. McKelvie devised a plan to suit the conditions of the country, whereby the essential and basic leprosaria were supplemented by mobile Landrover teams which brought care and treatment based on oral DDS to patients near their villages and homes. The eight Landrovers used at present over the whole country make regular stops daily at gatherings of patients, and the attendance rate at these "Landrover clinics" is higher than in static clinics. We had many opportunities of examining the patients treated by these mobile clinics, and there was no doubt that they were securing the die benefit. By the end of 1957, in the whole country some 30,000 patients were under treatment by all means and over 9,000 had already been discharged. Having seen the whole system at work, we are of the opinion that if Ghana enhances and continues its efforts it has a good chance of being the first African country to eradicate leprosy. We congratulate the present and previous Ghana Governments for their enlightened attitude and adequate expenditure, UNICEF for its generous participation by donating eight Landrovers and all the DDS used in therapy, all Missions for their hearty co-operation, the Ministry of Health and all members of the Ghana Leprosy Service for their faithful application to the task. It was sheer happiness to visit Ghana and see the good work done. 
The establishment of the Ghana Leprosy Service is:

1 specialist leprologist in charge of the leprosy service.

1 medical officer seconded to the leprosy service.

1 senior leprosy control officer.

9 leprosy control officers (2 vacancies).

4 assistant leprosy control officers.

18 leprosy control assistants.

8 pupil leprosy control assistants (probation: 2 years).

14 drivers ( 9 Landrovers, 2 Volkswagen buses, 1 ambulance,

2 trucks).

I nurse at Ankaful for the 90-bed hospital.

1 laboratory assistant.

5 office staff.

The 5 leprosaria are Ankaful, 500 patients, the headquarters of the service; Kokofu, for 200 patients, a new leprosarium with 60 patients so far; Ho, 100 patients, regional leprosarium for the Trans-Volta region; Yendi, 50 patients; Kpandai, 250 patients (W.E.C. Mission); Accra, 40 patients.

The regional figures for patients under treatment at December 1957 are:-

\begin{tabular}{|c|c|c|c|c|}
\hline Eastern Region ... & 2,869 & \multicolumn{3}{|c|}{ (520 lepromatous) } \\
\hline Western Region & 2,463 & $(532$ & ", & \\
\hline Ashanti $\ldots \quad \ldots \quad \ldots$ & 4,266 & $(420$ & , & \\
\hline Trans-Volta Togoland ... & 1,599 & (209 & , & \\
\hline Northern Region East... & 13,312 & $(887$ & & \\
\hline Nol thern Region West... & 5,097 & (289 & ", & \\
\hline
\end{tabular}

\section{Totals $\ldots \quad 29,606 \quad(2,857$ lepromatous $)$}

\section{Leprosy Survey of Sierra Leone, 1958}

Dr. C. M. Ross, O.B.E., senior leprologist in Northern Nigeria, has conducted a leprosy survey in Sierra Leone at the request of the Government, and in this was ably assisted on the field by Mrs. Ross and Mr. Alan Waudby (BelRA worker sent a short time before, who remains in Sierra Leone). This survey was carried out between 27th December, 1957, and 8th March, 1958. It is extremely valuable as it fills a gap in our modern knowledge of the leprosy endemic, and it provides a basis for an active future leprosy campaign in that country. The basic method of the survey was houseto-house or compound-to-compound visiting, and Dr. Ross examined and diagnosed all persons. In the Northern Province, 13,484 persons were examined and 763 leprosy cases found; in the South Western Province, 4,049 persons examined revealed 119 leprosy cases, and in the South Eastern Province 4,332 examined and 157 cases found. The three incidence rates are therefore 57, 29, and 36 per thousand. The estimate of the total number of existing cases is 85,000 , of whom 11,000 are lepromatous. Sierra Leone has a total population of 
$2,038,815$, an area of 27,540 square miles (about 71,000 sq. kilom.), and a density of population of 84.5 per square mile (about 33 per sq. kilom.). Missions have been the pioneers in the existing leprosy work in the country, and cover about 2,000 patients. Dr. Ross has recommended the construction of a leprosy service in Sierra Leone, including the founding of a focal base leprosarium, the training of staff, and the establishment of a clinic system, such as has been highly successful in Northern Nigeria. The hard work of Dr. Ross and his collaborators has provided Sierra Leone with the essential facts about its leprosy problem, and we look confidently to Sierra Leone for a dynamic response to the challenge of the facts, in which all intcrested agencies will stand ready to help.

\section{News of Leprosy in Nepal}

Dr. P. J. Chandy sends news of his experiences in Nepal. He has been there a year under the auspices of the Mission to Lepers.

Nepal is a mountainous country 50 miles long and 100 miles broad, and of high and varying altitudes above sea level. The estimated total population is $9,000,000$. The capital is Kathmandu, situated in a valley at 4,500 feet $(1,370 \mathrm{~m}$.) and contains a population in the valley of 400,000 . The inhabitants are almost entirely Mongoloid in blood. A regular leprosy survey has not been possible yet, but study has been made of patients attending a general hospital. In 1957, Dr. Chandy found 90 leprosy patients in 4,000 new cases attending for general treatment. Of these 90 cases, 40 knew that they had leprosy. He takes those who attend as an indicator of the true incidence, which therefore may be 12.5 per 1,000 of those attending hospital for various illnesses. For the whole population of the Kathmandu Valley, Dr. Chandy surmises that 10 per 1,000 might have leprosy. The neighbouring Indian provinces of Bengal, Bihar and Uttar Pradesh have much the same incidence of leprosy. Of the cases found in the Kathmandu Valley, 40 per cent were lepromatous and a fourth of the patients were females; only 2 cases were below fifteen years of age. There is considerable leprophobia and strict segregation of patents is enforced by the village headman. This is in the hilly parts; in the valley itself, the people are indifferent and make no restrictions on mixing and moving of leprosy patients. Beggars who have leprosy are required to report to the nearest Police Station and are interned at the leprosarium at Kockna, which can contain 500 patients. In Kockna, the patients are well fed and well clothed but proper medical treatment is lacking, though it certainly serves as a segregation centre for the valley. There is a leprosy officer who supervises four outpatient clinics at Pachali, Budha Nilkant, Thankot and Bhatgaon. The attendances are good at these clinics, though the sulphones have not yet been introduced. There is another segregation leprosarium at Mulungua in Western 
Nepal. It is inaccessible and hard to supervise. The Mission to Lepers has been given land 11 miles south of Kathmandu to establish a modern leprosarium. His Majesty's Government, therefore, have taken a good step forward. During Dr. Chandy's experience of a year in Nepal, watching over 100 leprosy patients under sulphone treatment, he noted that lepra reactions and fevers were uncommon. There were only 2 such cases. He had not used sulphone dosage over $400 \mathrm{mg}$. per week. There had been no anaemia and no sign of toxicity. The lower dosage has been preferred because the average Nepali, though well nourished, is seldom above $100 \mathrm{lb}$. (45.3 kg.) in weight.

\section{The Nature of the Mitsuda and the Kreim Reaction}

We draw attention to the abstract in this issue (page 166) of the extremely interesting paper by KoolJ and GerRITSEN dealing with this vital subject. From their 5 experiments, they conclude that the Kveim reaction is an expression of a sarcoid mode of reaction in certain individuals, with probably only quantitative differences in healthy perople, sarcoidosis patients, tuberculoid leprosy patients, and perhaps some other diseases; the disease sarcoidosis is a syndrome which can be evoked by many agents. Similarly the Mitsuda reaction also seems a sarcoid or tuberculoid form of foreign body reaction or an isomorphic phenomenon-a general tissue response to foreign bodies, such as leprosy bacilli and normal tissue particles. The absence of the Mitsuda reaction in the lepromatous type may be due to a fault in the reticulo-endothelial system. Certainly more study of the causes of its absence should open the way to a better understanding of leprosy.

\section{Cancellation of the Indian Arrangements for the International Congress}

The Secretary-Treasurer of the International Leprosy Association was informed on 9th June, 1958, by the Government of India that they greatly regret having to withdraw their invitation to hold the VII International Congress of Leprology in India, owing to difficulties of international political nature. The Congress therefore will not be held in India. It is too early yet to state what substitute arrangements can be made, but there is hope that it will be held somewhere this year.

LATEST NEWS 5-7-58

There is now a good chance of the Congress being held in Tokio on 12th November 1958, but final decision is awaited. 